\title{
Contemporary Research Methodologies in Technical Communication
}

\author{
Brian McNely \\ University of Kentucky \\ Clay Spinuzzi \\ University of Texas, Austin \\ Christa Teston \\ Ohio State University
}


Many tools, technologies, spaces, and practices of technical communication today bear little resemblance to those of the late 1990s, when Technical Communication Quarterly published its last special issue on research methods and methodologies. On the surface, this seems significant, for in the life of writing as a technology 15 years is not so long. As SchmandtBesserat (1986) illustrated, 5,000 years transpired between the first appearance of symbolic clay tokens and their impressed and incised signs in written systems of accounting and commerce (pp. 32-34). Similarly, humans have used various combinations of ink and paper for around 5,000 years (Fischer, 2011). Pen and paper persist for contemporary technical communicators, but new writing technologies have developed dramatically over the last two decades. The workflows of today's technical communicators are mediated by conditions that either did not exist or were not prevalent in the late 1990s: by new tools (always connected smartphones and touch screen devices, widely available eye-tracking systems for usability research, inexpensive and expansive digital storage); by new technologies (instant=text=multimedia messaging, social media, real-time collaborative document editing, nimble content management systems, Darwin information typing architecture); by new spaces (hybrid work locations, co-working venues, virtual offices); and by new practices (contextual design, user centered design, interaction design, single sourcing).

Recent special issues of this journal have explored many of these developments (Ding \& Savage, 2013; Kimme Hea, 2014; Pullman \& Gu, 2008; Spinuzzi, 2007; Swarts \& Kim, 2007). Although advances in technical communication research methodologies and methods have been substantial, the last special issue devoted to methodologies was published in 1998. In her introduction to that issue, Goubil-Gambrell argued that "defining research methods is a part of disciplinary development”' (p. 7). We agree that methodological approaches act as markers for disciplinary identity and changes to practices and theories of technical communication since the late 1990s serve as powerful exigencies for this special issue on contemporary research methodologies. Goubil-Gambrell claimed that articles in the 1998 special issue illustrated "where we are now" (p. 7); the work of authors in this special issue provide indicators of where we are in 2015, and how we are responding to substantive change in our field.

More important, the articles in this special issue not only respond to these changes but innovate and map future methodological approaches to technical communication. Since their work looks forward, we briefly look back - to some of the key methodological developments that have shaped our field's current research identity. We begin with sociocultural theories of writing and communication that were coincident with the 1998 special issue on research methodologies. This body of work inspired and built from qualitative studies of communicators in context. Next, we explore associative theories and methodologies that developed in parallel, but that carried alternative assumptions, methods, values, and aims about communicative actors, tools, and contexts. This body of scholarship and methodological practice changed ways in which researchers of communication explored and theorized human agency and mediation. We then consider recent work in the new material turn, a related but diverse set of approaches that is changing the ways that technical communication researchers study and understand contexts, distributed work, and collective labor. Last, we touch briefly on evolving adaptations of traditional qualitative methodologies; mixed methods approaches; and reconciliations of increasingly large technical communication data sets with situated, contextual research methods. We do all this as a way to situate the methodological contributions made by the articles in this special issue. 


\section{SOCIOCULTURAL THEORIES}

Scholars such as Bazerman (1988, 1994, 1997, 2013) Prior (1998, 2006, 2009), and Russell (1993, 1995, 1997a, 1997b, 2009, 2010) have been strong proponents of sociocultural theory in a variety of communicative contexts, and their work has influenced approaches in technical communication. "Sociocultural theory," according to Prior, "argues that activity is situated in concrete interactions that are simultaneously improvised locally and mediated by prefabricated, historically provided tools and practices'” (2006, p. 55; emphasis in original). Sociocultural theory has clear implications for methodologies and methods, influencing what objects and practices - beyond texts - are germane to researchers. Bazerman, Prior, and Russell draw on traditions of scholarship in social psychology, symbolic interactionism, and learning theory. For Prior (2006), attention to local contexts of situated activity is thus foundational to sociocultural theories. Writing is a protean form of situated activity, mediating and communicating abstract knowledge, practical know-how, and ways of being in the world. In sociocultural material surroundings of communicators matter because everyday activities are carried out and mediated by heterogeneous artifacts and tools (Prior, 2006).

In technical communication and related fields such as human-computer interaction (HCI) and computer-supported cooperative work (CSCW), similar methodological and theoretical approaches to contexts, artifacts, and human activity have been deployed. For example, situated action models (Brown, Collins, \& Duguid, 1989; Lave, 1988; Suchman, 1987) were grounded in contextual theories of learning and everyday practice. Nardi (1996) argued that a focus on practical activity and its epistemic effects in this approach "deemphasizes study of more durable, stable phenomena that persist across situations”' (p. 72). In theories and studies of distributed cognition (see, for example, Norman \& Hutchins, 1988, and Hutchins, 1991, 1995), however, the focus extends to tools, artifacts, and concepts that move across design problems (Nardi, p. 78). In distributed cognition, attention to the coordinative roles of tools, artifacts, and cognitive constructs stretch beyond particular situations and are reused and adapted to new or ongoing challenges (Nardi, p. 86). Scholars in rhetorical genre studies, also influenced by sociocultural theories, have explored such typification and durability in the form of genres (Artemeva \& Freedman, 2007; Bawarshi \& Reiff, 2010; Miller, 1984). The more recent synthesis of rhetorical genre studies and activity theory (known as writing, activity, and genre research or WAGR; see Russell, 2009; Spinuzzi, 2010) brings the durability and nomothetic potential of genres together with situated and ideographic explorations of specific contexts.

Indeed, Nardi (1996) argued that activity theory is a sociocultural approach that allows researchers in HCI and CSCW to study complex, situated contexts while producing findings that are generalizable (p. 70). Activity theory, which was introduced to professional communication via Bazerman (1988), Russell (1995, 1997a), and Berkenkotter and Huckin (1993), has been widely used in technical communication to study how genres are durable, suasive, and mediatory within specific activity systems (Fraiberg, 2013; Kain \& Wardle, 2005; McCarthy, Grabill, Hart-Davidson, \& McLeod, 2011), across linked activity systems (Gygi \& Zachry, 2010; McNair \& Paretti, 2010), and in broader networks (Ding, 2008; Propen \& Schuster, 2010; Sherlock, 2009; Spinuzzi, 2008, 2012). (For more detailed overviews of studies involving genre and activity theory, see Russell, 1997b; 2009.) Activity theory posits a clear asymmetry between communicators and their tools and technologies. In technical communication, activity-theoretical approaches have emphasized the motives and intentionality of individuals or collectives, 
positioning human subjects and material objects as distinct, yet interoperative. As Nardi argues, a key emphasis of activity theory is consciousness and motive, "which only belong to humans" (p. 86). Spinuzzi (2008) detailed another foundational perspective of activity theory that has particular methodological salience: Grounded in the work of social psychologists such as Vygotsky and Leontiev, activity theory is fundamentally genealogical and its accounts of human actions and intentions are therefore developmental.

Within those developmental parameters, sociocultural theories such as activity theory have anchored various methodological approaches in technical communication. For example, Mirel (1998, 2004) drew on sociocultural theory to outline her approach to interaction design, and Spinuzzi $(2003,2013)$ developed genre tracing as a methodology for information design. More recently, Sun (2012) drew on activity theory, genre theory, and articulation theory to develop Culturally Localized User Experience. In a 2006 interview with Zachry published in TCQ, Nardi described that in her article "'Objects of Desire" she was trying to stay "really close to the data"' (p. 493) and, to do so, paired activity theory with grounded theory (GT). Grounded theory approaches (Corbin \& Strauss, 2008; Farkas \& Haas, 2012; Glaser \& Strauss, 1967=2007; Strauss \& Corbin, 1990) afford analytic granularity and generalizable, formal theory building (for additional examples of GT approaches in technical communication, see Cooke, 2003; Mirel, Barton, \& Ackerman, 2008; Schuster, Russell, Bartels \& Kelly-Trombley, 2013; Scott, 2008; Spafford \& Schryer, 2010; Teston, 2009, 2012; Whithaus, 2012). Some of these approaches tend to draw on variations of interventionist methods and methodologies popularized in sociology, anthropology, cultural psychology, and computer-supported cooperative work. Yet, developmental approaches have their limitations. In particular, they assume a purposeful human actor who retains agency during processes of technical communication. However, this outlook is not the only productive one; other approaches have explored how agency, similar to cognition, can be understood across humans and nonhumans that have become associated in a system.

\section{ASSOCIATIVE THEORIES}

Associative theories analyze humans and nonhumans as parts of intersubjective systems across which agency and motives are stretched. Such theories do not necessarily deny individual agency or cognition, but they deemphasize the roles of individual human beings to avoid overdetermining human agency and underdetermining roles played by other parts of the system under consideration. By the 1990s, technical communication scholars had begun drawing in earnest from associative approaches such as articulation theory (Johnson-Eilola, 1997; Slack, Miller, \& Doak, 1993), rhizomatics (Selfe \& Selfe, 1994), distributed cognition (Freedman \& Smart, 1997; Winsor, 2001), and actor-network theory (Winsor, 1994). Of these, actor-network theory (ANT) has had perhaps the most uptake in technical communication and rhetoric, being used in a range of studies with various methodological commitments (Fleckenstein, Spinuzzi, Rickly, \& Clarke Papper, 2008; Fraiberg, 2013; McNely, 2009; Potts, 2009; Jeff Rice, 2009, 2012; Spinuzzi, 2005, 2008; Swarts, 2009, 2011).

Like other associative theories, ANT takes the position of symmetry-a methodological stance that ascribes agency to a network of human and nonhuman actors rather than to specific human actors. Methodologically, therefore, researchers focus on associations among nodes in an actor-network. And since associations themselves are the focus, things that they associate are 
considered network effects. Symmetry does not involve anthropomorphizing nonhumans or seeing humans as agentless media; instead, it involves focusing on how associations among them generate new possibilities.

This stance has implications for technical communication research methodologies that have been developed in different ways. For example, Jeff Rice (2009, 2012) applied ANT descriptively, tracing associations across networked and offline media to explore how identities emerge from these networks. Swarts $(2009,2011)$ focused on aspects of translation and networkbuilding in writing environments, and demonstrated how everyday issues such as technological literacy and reuse are developed rhetorically. Liza Potts (2009, 2014; see also Potts, Seitzinger, Jones, \& Harrison, 2011) took a modeling approach by mapping different actants and how they relate in networks across social media. Last, scholars such as Fleckenstein and colleagues (2008) and Spinuzzi and colleagues (2006) used an ecological approach that provided a holistic examination of texts-in-use and compared different moments of that use. These strands are not exclusive, and they draw on different methodologies to apply ANT insights in different ways.

\section{THE NEW MATERIAL TURN}

Associative approaches such as actor-network theory expand not only technical communication contexts but potential actors involved in such work. Latour (1992) suggested that nonhuman actors, in particular, are among the "missing masses" of collective life that participate in and shape experience (p. 152). Recent research across several disciplines (namely science and technology studies, political science, rhetoric, and philosophy) has extended associative and relational approaches to more directly engage the missing masses of nonhumans, taking seriously their potential role in affecting human work, and effecting ostensibly human activities and outcomes. In contrast to sociocultural theories, these approaches share a radically symmetrical perspective on relationships between humans and nonhumans-between people and things, whether those things are animal, vegetable, or mineral. Agency, from this perspective, is a function and emergent property of collectives: It is distributed and interdependent. Latour's (2013) term for this phenomenon is interagentivity - the capacity of humans and nonhumans to affect and effect one another beyond a subject-object bifurcation (p. 5). The development of these theories, we argue, will affect technical communication theory and methodology in years to come.

Emerging from a broad body of work in philosophy and political science (Barad, 2007; Bennett, 2010; Coole \& Frost, 2010) and scholarship often collected under the umbrella known as object-oriented ontology (not to be confused with object-oriented programming; see Bogost, 2012; Bryant, 2011; Harman, 2002, 2005, 2011; and Morton, 2007, 2013) these approaches constitute a new material turn. This scholarship is labeled "new" materialism because it considers materiality as something much more than the simple substrate upon which human designs and activity play out. In new materialisms, then, "things are not simply projections by, containers for, or artifacts of human activity: not fetishes but actors”' (McNely \& Rivers, 2014). Although some have called this brand of materialism new, others (in particular, those who align themselves with feminist materialism) would suggest there is nothing new at all about it. Yet, although research in technical communication and rhetoric has often focused on discursive relations and effects they generate among human actors, the radical symmetry of new materialism explores interagentive potentials by asking how things relate and produce effects as 
assemblages. Bennett (2010), for example, considers electrons, electromagnetic fields, and power lines as formidable actors in what we experience as " power" or "electricity" (p. 24). These actors are often unwilling to be shaped by human designs and intentions (Latour, 1988, p. 197); an interagentive view of electricity (and related technical communication concerns such as energy policy and usage restrictions), therefore, sees agency emerging from the humannonhuman assemblage rather than from human actors alone.

In scholarship of the new material turn, which increasingly influences work in technical communication and rhetoric (see, for example, Cooper, 2011; Gries, 2013; Hawk, 2011; Mara \& Hawk, 2009; McNely \& Rivers, 2014; Jenny Rice, 2012), things matter in robust ways, and nonhumans have suasive potentials that have been obfuscated by subject-object bifurcations (Latour, 2013). Rickert (2013), for example, invites us to reconsider information as not only a material context in which work is done, but also as "an ensemble of material elements bearing up, making possible, and continually incorporated in the conducting of human activity”' (p. 93). In Rickert's “'ambient rhetoric,' human activities such as technical communication are "'a stitchwork of material, practical, and discursive relations" (p. 93). From an ambient perspective, technical communication research and practice is often extractive: Our methods and methodologies seek salience about a particular concern-usability, collaboration, motivesallowing us (or, in a more cynical view, forcing us) to bracket the complexity of practical activity. In new materialist approaches, usability, collaboration, and motives of technical communicators are inseparable from the material environs in which knowledge work is practiced.

These theories, in short, have important methodological implications in the research of technical communication. Scholarship in the material turn has troubled how researchers should bound off and study objects and practices, given the potentially formidable roles such objects and material environs play in everyday work and in practical attunements of technical communicators to those environs (Rickert, 2013). New materialisms ask us to reconsider kinds of methodological commitments and values we should deploy when attempting to capture the complexity of objects and their role in everyday ontologies. For example, Dourish and Bell (2011) make a case for infrastructure as an object of study, and, when exploring mess and myths associated with ubiquitous computing, they adopt an ethnographic approach. They eschew, however, the editorial imperative to, upon completing the ethnography, make recommendations for improvements upon technological design. For them, ethnography is "scenic fieldwork" (p. 67) and serves to "reveal certain underlying logics of social practice", (p. 69)—not render recommendations for the elimination of a problem.

\section{LOOKING FORWARD: PREVIEWING THE SPECIAL ISSUE ON RESEARCH METHODOLOGIES}

In some ways, associative theories and work in the material turn bring us back to where we began: theory building about social practices of technical communication-including all their messiness, failures, and fraught, mutually constitutive associations. Methodologies influenced by new materialisms and associative theories, however, broaden the scope of social and rhetorical aspects of technical communication and encourage us to consider tools, technologies, and environs as potentially interagentive elements of practice. Although the three broad theoretical trends we have briefly outlined have shaped methodologies in technical 
communication, so too have innovations in qualitative approaches. For example, work in action research (Blythe, Grabill, \& Riley, 2008; Grabill, 2003), work in participatory design (Evia \& Patriarca, 2012; Simmons, 2007; Spinuzzi, 2005), and work in visual methods (Evia \& Patriarca, 2012; McNely, 2013; McNely, Gestwicki, Gelms, \& Burke, 2013; Varpio, Spafford, Schryer, \& Lingard, 2007) have adapted and extended traditional qualitative approaches for nuances of contemporary technical communication. In addition, given the increasing importance of so-called "big data" in a variety of knowledge work fields, mixed methods and statistical approaches to technical communication are likely to become more prominent. We believe a formidable methodological challenge in coming years will be to explore increasingly large data sets with innovative methods while remaining grounded in the values and aims that have guided technical communication methodologies over the previous three decades. In the hot-air balloon view of our discipline, methodological and theoretical pluralism reveals the rich and diverse tapestry of opportunities for research and practice.

The 1998 special issue of TCQ on research methodologies established new directions in how technical communication researchers, teachers, and practitioners would understand and explore the field's objects of study, research ethics, and metrics (see Table 1). In this 2015 special issue, each contribution reflects how technical communication's methods and methodologies have developed further — and along various paths — to better address many new objects of study, new aspects of research ethics, new metrics that have emerged alongside developments in theory, new research opportunities and modes, and new technologies.

TABLE 1

Comparing TCQ's 1998 and 2015 Special Issues on Research Methods and Methodologies Based on Key Methodo-Communicative Issues

\begin{tabular}{|c|c|c|}
\hline Methodo-Communicative Issues & 1998 & 2015 \\
\hline $\begin{array}{l}\text { OBJECTS OF STUDY. How do we } \\
\text { account for contexts, people, } \\
\text { things, objects? }\end{array}$ & $\begin{array}{l}\text { Longo is attentive to contextual } \\
\text { nature of technical communication. }\end{array}$ & $\begin{array}{l}\text { Read and Swarts are attentive to } \\
\text { networks and knowledge work. }\end{array}$ \\
\hline $\begin{array}{l}\text { ETHICS. How do (and should) we } \\
\text { cross borders? }\end{array}$ & $\begin{array}{l}\text { Blyler deploys critical (e.g., feminist; } \\
\text { participatory action) methods vs. } \\
\text { descriptive/explanatory methods. } \\
\text { Johnson sees interdisciplinarity as an } \\
\text { ethic. }\end{array}$ & $\begin{array}{l}\text { Walton, Zraly, and Mugengana } \\
\text { see visual methods as a way to } \\
\text { deploy ethically sound } \\
\text { cross-cultural, } \\
\text { community-based research. }\end{array}$ \\
\hline $\begin{array}{l}\text { MEASUREMENT. What's our } \\
\text { metric? What counts as data? }\end{array}$ & $\begin{array}{l}\text { Charney asks, what does empiricism, } \\
\text { romanticism afford us? }\end{array}$ & $\begin{array}{l}\text { Graham, Kim, Hartke, and Keith } \\
\text { ask, what does statistical genre } \\
\text { analysis of larger data sets } \\
\text { afford us? }\end{array}$ \\
\hline
\end{tabular}

This special issue extends some of these theoretical and methodological trends in innovative ways, describing and deploying perspectives that allow us to better apply their insights to technical communication research questions (see Table 2).

In "Visualizing and Tracing: Articulated Research Methodologies for the Study of Networked, Sociotechnical Activity, Otherwise Known as Knowledge Work,'” Read and Swarts 
address the question of how to conduct a principled network analysis. Taking the network as their object of study, they bring together and place into conversation two very different methodological perspectives, using actor-network theory and social network analysis to develop

TABLE 2

The Current Issue's Contributions to Methodo-Communicative Issues

\begin{tabular}{|c|c|c|}
\hline $\begin{array}{l}\text { Methodo-Communicative } \\
\text { Issues }\end{array}$ & 2015 & What's New (or 'Where Are We Now?') \\
\hline $\begin{array}{l}\text { OBJECTS OF STUDY. How } \\
\text { do we account for contexts, } \\
\text { people, things, objects? }\end{array}$ & $\begin{array}{l}\text { Read and Swarts model how to study } \\
\text { networks and knowledge work. }\end{array}$ & $\begin{array}{l}\text { Networks are an object of study; network } \\
\text { analysis is one method for capturing } \\
\text { their complexity. } \\
\text { Theoretical ancestry: science and } \\
\text { technology studies; actor-network } \\
\text { theory; social network analysis }\end{array}$ \\
\hline $\begin{array}{l}\text { ETHICS. How do (and } \\
\text { should) we cross borders? }\end{array}$ & $\begin{array}{l}\text { Walton, Zraly, and Mugengana model } \\
\text { visual methods as a way to engage } \\
\text { ethically in cross-cultural, } \\
\text { community-based research. }\end{array}$ & $\begin{array}{l}\text { Values and validity should be considered } \\
\text { in cross-cultural research; visual } \\
\text { research methods as a way to do that. } \\
\text { Theoretical ancestry: anthropology }\end{array}$ \\
\hline $\begin{array}{l}\text { MEASUREMENT. What's our } \\
\text { metric? What counts as } \\
\text { data? }\end{array}$ & $\begin{array}{l}\text { Graham, Kim, Hartke, and Keith model } \\
\text { how to conduct statistical genre analysis } \\
\text { of larger data sets. }\end{array}$ & $\begin{array}{l}\text { Larger data sets can be analyzed } \\
\text { rhetorically using statistics' } \\
\text { methodological affordances. } \\
\text { Theoretical ancestry: rhetorical studies, } \\
\text { linguistics, science and technology } \\
\text { studies, statistics }\end{array}$ \\
\hline
\end{tabular}

a synchronic view of how work is distributed spatially, temporally, and disciplinarily at an interdisciplinary, project-based research environment called the CIRCUIT Studio. Moreover, Read and Swarts provide visual tools for understanding this distributed work, and their methodological innovation offers incisive implications for how we understand knowledge work in such organizations.

Walton, Zraly, and Mugengana explore methodological processes in "Values and Validity: Navigating Messiness in a Community-Based Research Project in Rwanda.’' In particular, they consider the issue of how to develop and enact research ethics in communitybased, translingual fieldwork. Qualitative fieldwork is inherently messy, and community-based, translingual research may involve additional considerations for technical communication research, such as adjusting mutually with community stakeholders throughout the research process. Walton, Zraly, and Mugengana describe how to negotiate research objectives while democratically sharing power with community stakeholders, maximizing rigor, and navigating uncertainty. By drawing lessons from their developmental processes, they provide valuable guidance for others who plan to do similar research.

Over the past two decades, technical communication researchers have performed many qualitative field studies, but comparatively few textual studies deployed techniques of statistical analysis. In "'Statistical Genre Analysis: Toward Big Data Methodologies in Technical Communication,’' Graham, Kim, Hartke, and Keith develop a statistical approach to perform a genre analysis on a data set whose size would be too large for the techniques typically used in rhetorical genre studies. In this analysis of deliberations conducted by the U.S. Food and Drug Administration's Oncologic Drugs Advisory Committee, the authors pilot a big data approach to genre analysis, one that allows them to systematically investigate effects of industry and stakeholder inclusion in science-policy deliberation. Through their hybrid methodological approach, the authors argue, genres can be defined with more precision-not based on 
individual cases but across the entire data set—and specific genre features can be correlated with specific outcomes.

These three articles represent and frame very different methodological developments in technical communication research. In ' Getting to 'How Do You Know?' Rather than 'So What?' from 'What's New?', ' Davida Charney puts these articles into context by discussing how they relate to various technical communication research trajectories. More important, she considers some fundamental moves in our work by asking: Where do we begin? How do we frame our research? Where are the failures, dysfunctions, and conflicts? And, ultimately, how do we know?

This issue also includes reviews of recent books that we see as key methodological resources for technical communication researchers. First, Hashimov reviews what he calls two "'musthave”' books for qualitative researchers: Miles, Huberman, and Salda na's (2014) Qualitative Data Analysis: A Methods Sourcebook and Salda na’s (2013) The Coding Manual for Qualitative Researchers. Hashimov discusses how readers will find useful each source's systematic approach to qualitative data collection, coding, analysis, and presentation. In her review of Johnson-Eilola and Selber's (2013) edited collection, Solving Problems in Technical Communication, Elizabeth Angeli argues for the value of this book's technical communication heuristics for undergraduate and graduate students, but she also invites readers to imagine an additional chapter that might have provided an overview of research methods technical communicators could use to solve problems (e.g., basic statistics, coding, eye-tracking). Last, Lambert reviews Potts' (2014) Social Media in Disaster Response as a model for the kind of methodological complexity contemporary technical communication researchers encounter, particularly when studying user-centered design and social media in the context of tragic events.

The 1998 TCQ special issue on research methodologies was a landmark issue that informed a generation of technical communication scholars as they defined their own objects of study, enacted their research ethics, and thought through their metrics. We hope that this special issue will similarly provide valuable grounding for technical communication researchers in the years to come.

\section{ACKNOWLEDGEMENTS}

The authors extend thanks to everyone involved in this special issue. In particular, the authors thank TCQ's previous editor Amy Koerber, who greenlighted this project, as well as the current editor, Donna Kain, who brought it to fruition. The authors also thank the TCQ editorial board for accepting their special issue proposal. The authors thank, too, the many reviewers who provided measured and thoughtful reviews. Most of all, the authors extend thanks to the authors in this special issue.

\section{REFERENCES}

Artemeva, N., \& Freedman, A. (Eds.). (2007). Rhetorical genre studies and beyond. Winnipeg, Manitoba: Inkshed Publications.

Barad, K. (2007). Meeting the universe halfway: Quantum physics and the entanglement of matter and meaning. Durham, NC: Duke University Press.

Bawarshi, A., \& Reiff, M. J. (2010). Genre: An introduction to history, theory, research, and pedagogy. West Lafayette, 


\section{IN: Parlor Press.}

Bazerman, C. (1988). Shaping written knowledge: The genre and activity of the experimental article in science. Madison: University of Wisconsin Press.

Bazerman, C. (1994). Systems of genre and the enactment of social intentions. In A. Freedman \& P. Medway (Eds.), Genre and the new rhetoric (pp. 79-99). Bristol, PA: Taylor \& Francis.

Bazerman, C. (1997). Discursively structured activities. Mind, Culture, and Activity, 4, 296-308.

Bazerman, C. (2013). A rhetoric of literate action (Vols. 1-2). Fort Collins, CO: The WAC Clearinghouse and Parlor Press.

Bennett, J. (2010). Vibrant matter: A political ecology of things. Durham, NC: Duke University Press.

Berkenkotter, C., \& Huckin, T. (1993). Rethinking genre from a sociocognitive perspective. Written Communication, 10, 475-509.

Blythe, S., Grabill, J., \& Riley, K. (2008). Action research and wicked environmental problems: Exploring appropriate roles for researchers in professional communication. Journal of Business and Technical Communication, 22, $272-298$. Bogost, I. (2012). Alien phenomenology, or what it's like to be a thing. Minneapolis: University of Minnesota Press. Brown, J. S., Collins, A., \& Duguid, P. (1989). Situated cognition and the culture of learning. Educational Researcher, 18, 32-42.

Bryant, L. (2011). The democracy of objects. Ann Arbor: University of Michigan Press.

Cooke, L. (2003). Information acceleration and visual trends in print, television, and web news sources. Technical Communication Quarterly, 12, 155-181.

Coole, D., \& Frost, S. (2010). New materialisms: Ontology, agency, and politics. Durham, NC: Duke University Press. Cooper, M. (2011). Rhetorical agency as emergent and enacted. College Composition and Communication, 62, 420-449. Corbin, J., \& Strauss, A. (2008). Basics of qualitative research: Grounded theory procedures and techniques (3rd ed.). Newbury Park, CA: Sage.

Ding, H. (2008). The use of cognitive and social apprenticeship to teach a disciplinary genre: Initiation of graduate students into NIH grant writing. Written Communication, 25, 3-52.

Ding, H., \& Savage, G. (2013). Guest editor's introduction: New directions in intercultural professional communication. Technical Communication Quarterly, 22, 1-9.

Dourish, P., \& Bell, G. (2011). Divining a digital future: Mess and mythology in ubiquitous computing. Cambridge, MA: MIT Press.

Evia, C., \& Patriarca, A. (2012). Beyond compliance: Participatory translation of safety communication for Latino construction workers. Journal of Business and Technical Communication, 26, 340-367.

Farkas, K., \& Haas, C. (2012). A grounded theory approach for studying writing and literacy. In K. Powell \& P. Takayoshi (Eds.), Practicing research in writing studies: Reflexive and ethically responsible research (pp. 81-96). New York, NY: Hampton Press.

Fischer, S. (2011). A history of writing. London, England: Reaktion Books.

Fleckenstein, K., Spinuzzi, C., Rickly, R., \& Clarke Papper, C. (2008). The importance of harmony: An ecological metaphor for writing research. College Composition and Communication, 60, 388-419.

Fraiberg, S. (2013). Reassembling technical communication: A framework for studying multilingual and multimodal practices in global contexts. Technical Communication Quarterly, 22, 10-27.

Freedman, A., \& Smart, G. (1997). Navigating the current of economic policy: Written genres and the distribution of cognitive work at a financial institution. Mind, Culture, and Activity, 4, 238-255.

Glaser, B., \& Strauss, A. (2007). The discovery of grounded theory: Strategies for qualitative research. Piscataway, NJ: Aldine Transaction. (Original work published 1967)

Goubil-Gambrell, P. (1998). Guest editor’s column. Technical Communication Quarterly, 7, 5-7.

Grabill, J. T. (2003). Community computing and citizen productivity. Computers and Composition, 20, 131-150.

Gries, L. (2013). Iconographic tracking: A digital research method for visual rhetoric and circulation studies. Computers and Composition, 30, 332-348.

Gygi, K., \& Zachry, M. (2010). Productive tensions and the regulatory work of genres in the development of an engineering communication workshop in a transnational corporation. Journal of Business and Technical

Communication, 24, 358-381.

Harman, G. (2002). Tool-being: Heidegger and the metaphysics of objects. Chicago, IL: Open Court.

Harman, G. (2005). Guerrilla metaphysics: Phenomenology and the carpentry of things. Chicago, IL: Open Court.

Harman, G. (2011). The quadruple object. Washington, DC: Zero Books.

Hawk, B. (2011). Vitalism, animality, and the material grounds of rhetoric. In J. Packer \& S. Wiley (Eds.), Communication matters: Materialist approaches to media, mobility and networks (pp. 196-207). New York, NY: Routledge.

Hutchins, E. (1991). The social organization of distributed cognition. In L. Resnick, J. Levine, \& S. Teasley (Eds.),

Perspectives on socially shared cognition (pp. 283-307). Washington, DC: APA Press.

Hutchins, E. (1995). Cognition in the wild. Cambridge, MA: MIT Press.

Johnson-Eilola, J. (1997). Nostalgic angels: Rearticulating hypertext writing. Norwood, NJ: Ablex Press.

Kain, D., \& Wardle, E. (2005). Building context: Using activity theory to teach about genre in multi-major professional communication courses. Technical Communication Quarterly, 14, 113-139.

Kimme Hea, A. (2014). Guest editor's introduction: Social media in technical communication. Technical Communication Quarterly, 23, 1-5.

Latour, B. (1988). The pasteurization of France. Cambridge, MA: Harvard University Press.

Latour, B. (1992). Where are the missing masses? The sociology of a few mundane artefacts. In W. Bijker \& J. Law

(Eds.), Shaping technology—Building society (pp. 225-259). Cambridge, MA: MIT Press. 
Latour, B. (2013, November). Another way to compose the common world. An executive session of the American Anthropological Association Annual Meeting, Chicago, IL. In HAU: Journal of Ethnographic Theory, 4, 301-307. Lave, J. (1988). Cognition in practice: Mind, mathematics, and culture in everyday life. New York, NY: Cambridge University Press.

Mara, A., \& Hawk, B. (2009). Posthuman rhetorics and technical communication. Technical Communication Quarterly, 19, 1-10.

McCarthy, J. E., Grabill, J. T., Hart-Davidson, W., \& McLeod, M. (2011). Content management in the workplace: Community, context, and a new way to organize writing. Journal of Business and Technical Communication, 25, 367-395.

McNair, L. D., \& Paretti, M. C. (2010). Activity theory, speech acts, and the "doctrine of infelicity”: Connecting language and technology in globally networked learning environments. Journal of Business and Technical Communication, 24, 323-357.

McNely, B. (2009). Backchannel persistence and collaborative meaning-making. In SIGDOC '09: Proceedings of the 27th annual international conference on design of communication (pp. 297-304). New York, NY: ACM.

McNely, B. (2013). Visual research methods and communication design. In K. Gossett (Ed.), SIGDOC '13:

Proceedings of the 31st Annual International Conference on Design of Communication (pp. 123-132). New York, NY: ACM.

McNely, B., Gestwicki, P., Gelms, B., \& Burke, A. (2013). Spaces and surfaces of invention: A visual ethnography of game development. Enculturation, 15. Retrieved from http://enculturation.net/visual-ethnography

McNely, B., \& Rivers, N. (2014). All of the things: Engaging complex assemblages in communication design. In D. L. Jones \& B. McNely (Eds.), SIGDOC '14: Proceedings of the 32nd Annual International Conference on Design of Communication (pp. 1-10). New York, NY: ACM Press.

Miller, C. R. (1984). Genre as social action. Quarterly Journal of Speech, 70, 151-167.

Mirel, B. (1998). “Applied constructivism” for user documentation. Journal of Business and Technical Communication, 12, 7-49.

Mirel, B. (2004). Interaction design for complex problem solving: Developing useful and usable software. San Francisco, CA: Morgan Kaufmann.

Mirel, B., Barton, E., \& Ackerman, M. S. (2008). Researching telemedicine: Capturing complex clinical interactions with a simple interface design. Technical Communication Quarterly, 17, 358-378.

Morton, T. (2007). Ecology without nature: Rethinking environmental aesthetics. Cambridge, MA: Harvard University Press.

Morton, T. (2013). Hyperobjects: Philosophy and ecology after the end of the world. Minneapolis: University of Minnesota Press.

Nardi, B. A. (1996). Studying context: A comparison of activity theory, situated action models, and distributed cognition. In B. Nardi (Ed.), Context and Consciousness: Activity theory and human-computer interaction (pp. 69-102).

Cambridge, MA: MIT Press.

Nardi, B. (2005). Objects of desire: Power and passion in collaborative activity. Journal of Mind, Culture and Activity, 12, 37-51.

Norman, D., \& Hutchins, E. (1988). Computation via direct manipulation. Final Report: ONR Contract N0001485-C-0133. La Jolla: University of California, San Diego, Institute for Cognitive Science.

Potts, L. (2009). Using actor network theory to trace and improve multimodal communication design. Technical Communication Quarterly, 18, 281-301.

Potts, L. (2014). Social media in disaster response. London, England: Routledge.

Potts, L., Seitzinger, J., Jones, D., \& Harrison, A. (2011). Tweeting disaster: Hashtag constructions and collisions. In C. J. Costa \& C. Meghini (Eds.), SIGDOC '11: Proceedings of the 29th annual international conference on design of communication (pp. 235-240). New York, NY: ACM.

Prior, P. (1998). Writing=disciplinarity: A sociohistoric account of literate activity in the academy. Mahwah, NJ: Erlbaum. Prior, P. (2006). A sociocultural theory of writing. In C. MacArthur, S. Graham, \& J. Fitzgerald (Eds.), Handbook of writing research (pp. 54-66). New York, NY: Guilford Press.

Prior, P. (2009). From speech genres to mediated multimodal genre systems: Bakhtin, Voloshinov, and the question of writing. In C. Bazerman, A. Bonini, \& D. Figueiredo (Eds.), Genre in a changing world (pp. 17-34). Fort Collins, CO: The WAC Clearinghouse and Parlor Press.

Propen, A. D., \& Schuster, M. L. (2010). Understanding genre through the lens of advocacy: The rhetorical work of the Victim Impact Statement. Written Communication, 27, 3-35.

Pullman, G., \& Gu, B. (2007). Guest editor’s introduction: Rationalizing and rhetoricizing content management. Technical Communication Quarterly, 17, 1-9.

Rice, J. (2009). Networked exchanges, identity, writing. Journal of Business and Technical Communication, 23, $294-317$. Rice, J. [Jeff]. (2012). Digital Detroit: Rhetoric and space in the age of the network. Carbondale, IL: SIU Press.

Rice, J. [Jenny]. (2012). Distant publics: Development rhetoric and the subject of crisis. Pittsburgh, PA: Pittsburgh University Press.

Rickert, T. (2013). Ambient rhetoric: The attunements of rhetorical being. Pittsburgh, PA: University of Pittsburgh Press. Russell, D. R. (1993). Vygotsky, Dewey, and externalism: Beyond the student=discipline dichotomy. Journal of Advanced Composition, 13, 173-197.

Russell, D. R. (1995). Activity theory and its implications for writing instruction. In J. Petraglia (Ed.), Reconceiving writing, rethinking writing instruction (pp. 51-76). Mahwah, NJ: Erlbaum.

Russell, D. R. (1997a). Rethinking genre in school and society: An activity theory analysis. Written Communication, 
14, 504-54.

Russell, D. R. (1997b). Writing and genre in higher education and workplaces: A review of studies that use cultural-historical activity theory. Mind, Culture, and Activity, 4, 224-237.

Russell, D. R. (2009). Uses of activity theory in written communication research. In A. Sannino, H. Daniels, \&

K. D. Gutierrez (Eds.), Learning and expanding with activity theory (pp. 40-52). New York, NY: Cambridge University Press.

Russell, D. R. (2010). Writing in multiple contexts: Vygotskian CHAT meets the phenomenology of genre. In

C. Bazerman, R. Krut, K. Lunsford, S. McLeod, S. Null, P. Rogers, \& A. Stansell (Eds.), Traditions of writing research (pp. 353-364). New York, NY: Routledge.

Schmandt-Besserat, D. (1986). The origins of writing: An archaeologist’s perspective. Written Communication, 3, 31-45.

Schuster, M. L., Russell, A. L. B., Bartels, D. M., \& Kelly-Trombley, H. (2013). “Standing in Terri Shiavo’s shoes”’: The role of genre in end-of-life decision making. Technical Communication Quarterly, 22, 195-218.

Scott, J. B. (2008). The practice of usability: Teaching user engagement through service-learning. Technical Communication Quarterly, 17, 381-412.

Selfe, C., \& Selfe, R. (1994). The politics of the interface: Power and its exercise in electronic contact zones. College Composition and Communication, 45, 480-504.

Sherlock, L. (2009). Genre, activity, and collaborative work and play in world of warcraft: Places and problems of open systems in online gaming. Journal of Business and Technical Communication, 23, 263-293.

Simmons, W. M. (2007). Participation and Power. Albany, NY: SUNY Press.

Slack, J., Miller, D., \& Doak, J. (1993). The technical communicator as author: Meaning, power, authority. Journal of Business and Technical Communication, 7, 12-36.

Spafford, M. M., Schryer, C. F., Lingard, L., \& Mian, M. (2010). Accessibility and order: Crossing borders in child abuse forensic reports. Technical Communication Quarterly, 19, 118-143.

Spinuzzi, C. (2003). Tracing genres through organizations: A sociocultural approach to information design. Cambridge, MA: MIT Press.

Spinuzzi, C. (2005). Lost in the translation: Shifting claims in the migration of a research technique. Technical

Communication Quarterly, 14, 411-446.

Spinuzzi, C. (2007). Guest editor’s introduction: Technical communication in the age of distributed work. Technical

Communication Quarterly, 16, 265-277.

Spinuzzi, C. (2008). Network: Theorizing knowledge work in telecommunications. New York, NY: Cambridge

University Press.

Spinuzzi, C. (2010). Secret sauce and snake oil: Writing monthly reports in a highly contingent environment. Written Communication, 27, 363-409.

Spinuzzi, C. (2012). Working alone, together: Coworking as emergent collaborative activity. Journal of Business and Technical Communication, 26, 399-441.

Spinuzzi, C. (2013). Topsight: A guide to studying, diagnosing, and fixing information flow in organizations. Austin, TX: Amazon CreateSpace.

Spinuzzi, C., Hart-Davidson,W., \& Zachry,M. (2006). Chains and ecologies: Methodological notes toward a communicative mediationalmodel of technologically mediated writing. In R. Pierce \& J. Stamey (Eds.), SIGDOC '06: Proceedings of the 24th Annual International Conference on Design of Communication (pp. 43-50). New York, NY: ACM.

Strauss, A., \& Corbin, J. (1990). Basics of qualitative research: Grounded theory procedures and techniques. Newbury Park, CA: Sage.

Suchman, L. A. (1987). Plans and situated actions: The problem of human-machine communication. New York, NY: Cambridge University Press.

Sun, H. (2012). Cross-cultural technology design: Crafting culture-sensitive technology for local users. New York, NY: Oxford University Press.

Swarts, J. (2009). Recycled writing: Assembling actor networks from reusable content. Journal of Business and Technical Communication, 24, 127-163.

Swarts, J. (2011). Technological literacy as network building. Technical Communication Quarterly, 20, 274-302.

Swarts, J., \& Kim, L. (2007). Guest editor’s introduction: New technological spaces. Technical Communication Quarterly, 23, 211-223.

Teston, C. B. (2009). A grounded investigation of gendered guidelines in cancer care deliberations. Written Communication, 26, 320-348.

Teston, C. B. (2012). Moving from artifact to action: A grounded investigation of visual displays of evidence during medical deliberations. Technical Communication Quarterly, 21, 187-209.

Varpio, L., Spafford, M. M., Schryer, C. F., \& Lingard, L. (2007). Seeing and listening: A visual and social analysis of optometric record-keeping practices. Journal of Business and Technical Communication, 21, 343-375.

Whithaus, C. (2012). Claim-evidence structures in environmental science writing: Modifying Toulmin’s model to account for multimodal arguments. Technical Communication Quarterly, 21, 105-128.

Winsor, D. A. (1994). Invention and writing in technical work: Representing the object. Written Communication, $11,227-250$.

Winsor, D. A. (2001). Learning to do knowledge work in systems of distributed cognition. Journal of Business and Technical Communication, 15, 5-28.

Zachry, M. (2006). Interview with Bonnie A. Nardi. Technical Communication Quarterly, 15, 483-503. 
Brian McNely is an assistant professor of writing, rhetoric, and digital studies at the University of Kentucky. He studies everyday genres, technologies, objects, and practices of communication using qualitative methodologies and visual research methods.

Clay Spinuzzi is a professor of rhetoric and writing at the University of Texas at Austin. He studies how people organize, communicate, collaborate, and innovate at work. Spinuzzi has conducted multiple workplace studies, resulting in several articles and four books: Tracing Genres through Organizations (MIT Press, 2003); Network (Cambridge University Press, 2008); Topsight (Amazon CreateSpace, 2013); and All Edge (University of Chicago Press, 2015). He blogs at spinuzzi.blogspot.com.

Christa Teston is an assistant professor at The Ohio State University in Columbus, Ohio. She investigates how people- - through texts, images, statistical constructions, and other embodied sensory input-manage uncertainty. Her research sites include complex, collaborative, technologically mediated workplaces wherein scientific and medical decision making takes place. 